\title{
Translation and cross-cultural adaptation of the Temperament \& Personality Questionnaire into Brazilian Portuguese
}

\author{
Tradução e adaptação cultural para o português brasileiro do Temperament \\ and Personality Questionnaire
}

Lucas Spanemberg, ${ }^{1,2}$ Gordon Parker, ${ }^{3}$ Marco Antonio Caldieraro, ${ }^{1}$ Edgar Arrua Vares, ${ }^{1}$ Fernanda Costa, ${ }^{1}$ Manuela Martins Costa, ${ }^{1}$ Marcelo Pio Fleck ${ }^{1}$

\begin{abstract}
Introduction: The Temperament \& Personality Questionnaire (T\&P) is a self-report instrument designed to evaluate personality styles overrepresented in patients with depression. This report briefly describes the translation and adaptation of the T\&P into Brazilian Portuguese.

Methods: The procedures, which included 10 steps, followed guidelines for the adaptation of self-report instruments defined by the International Society For Pharmacoeconomics and Outcomes Research (ISPOR) Task Force for Translation and Cultural Adaptation.

Results: The author of the original T\&P questionnaire authorized and participated in the translation conducted by the authors and independent native speakers. Evaluation of the translated questionnaire indicated that only minor adjustments were required in the Portuguese version.

Conclusions: The Brazilian version of T\&P, translated and adapted following a rigid standardized process, is available for use free of charge and may be especially useful in pursuing links between personality styles and depressive conditions.

Keywords: Translation, personality, depressive disorder, self-report questionnaire.
\end{abstract}

\section{Resumo}

Introdução: O Temperament \& Personality Questionnaire (T\&P) é um instrumento de autorrelato criado para avaliar quais estilos de personalidade têm maior representação em pacientes com depressão. Este trabalho descreve brevemente o processo de tradução e adaptação do T\&P para o português brasileiro.

Métodos: A tradução e a adaptação cultural se desenvolveram em 10 passos e seguiram as diretrizes para adaptação de instrumentos de autorrelato definidas por força-tarefa do ISPOR (International Society For Pharmacoeconomics and Outcomes Research).

Resultados: $O$ autor do questionário T\&P original autorizou e participou da tradução feita pelos autores e por falantes nativos independentes. A avaliação do questionário traduzido mostrou que apenas pequenos ajustes foram necessários na versão em português.

Conclusões: A versão brasileira do questionário T\&P, traduzido e adaptado seguindo um rígido processo padronizado, está disponível gratuitamente e pode ser de grande utilidade na pesquisa sobre as relações entre estilos de personalidade e quadros depressivos.

Descritores: Tradução, personalidade, transtornos depressivos, questionário de autorrelato.

\footnotetext{
${ }_{1}^{1}$ Mood Disorders Program, Hospital de Clínicas de Porto Alegre (HCPA), Universidade Federal do Rio Grande do Sul (UFRGS), Porto Alegre, RS, Brazil. 2 Department of Psychiatry, Hospital São Lucas, Pontifícia Universidade Católica do Rio Grande do Sul (PUCRS), Porto Alegre, RS, Brazil. ${ }^{3}$ School of Psychiatry, University of New South Wales and Black Dog Institute, Sydney, Australia.

Financial support: Coordenação de Aperfeiçoamento de Pessoal de Nível Superior (CAPES).

Submitted Feb 02 2014, accepted for publication Jun 042014.

Conflicts of interest: Gordon Parker has received honoraria from Astra Zeneca, Eli Lilly, GlaxoSmithKline, Pfizer and Servier. No other conflicts of interest declared concerning the publication of this article.

Suggested citation: Spanemberg L, Parker G, Caldieraro MA, Vares EA, Costa F, Costa MM, et al. Translation and cross-cultural adaptation of the Temperament \& Personality Questionnaire into Brazilian Portuguese. Trends Psychiatry Psychother. 2014;36(4):214-218. http://dx.doi.org/10.1590/2237-6089-2014-1007
} 


\section{Introduction}

Personality and psychopathology have been variably associated along history. ${ }^{1}$ Their interactions may exist in different forms and may be associated with a model of vulnerability, as certain disordered personality traits may predispose to psychopathology (e.g., clinical depression). ${ }^{2}$

Various personality models and structures have been described, and current models suggest that personality is hierarchically organized, with broad higher-order (molar) traits that subdivide into specific lower-order (facet) traits. ${ }^{3}$ The Five Factor Model (FFM), the most widely accepted model of normal personality, ${ }^{4}$ has been used extensively in studies of depression, but it is weighted to molar constructs and, therefore, has some limitations. ${ }^{5,6}$ As most personality dimensions show some level of interdependence, a hierarchical model that includes molar constructs and their constituent facets may overcome those limitations to some degree. Furthermore, the FFM is limited in that it does not assess some personality styles relevant to a predisposition to depressive disorders, such as rejection sensitivity, a central feature of atypical depression. ${ }^{7}$

Parker et al. ${ }^{7}$ suggested that some forms of non-melancholic depression are a consequence of predisposing personality styles and undertook several studies to define and refine such candidate personality styles. $^{6-11}$ Their studies have led to a flexible self-report measure of personality, ${ }^{6}$ the Temperament \& Personality Questionnaire (T\&P). ${ }^{12}$ This tiered instrument is used to evaluate molar constructs and a series of lower-order personality styles overrepresented in individuals with depressive disorders according to a bottom-up approach irrespective of any model of personality. Although its English version has been used in numerous studies, T\&P has been minimally used in other languages. ${ }^{13}$ This report summarizes the process of translation and cultural adaptation (TCA) of the T\&P from English into Brazilian Portuguese and briefly describes its final version.

\section{Methods}

\section{The Temperament \& Personality Questionnaire (T\&P)}

The T\&P is a 109-item self-report questionnaire with 10 subscales, eight for the assessment of personality styles (89 items) and two for disordered personality functioning (10 items for non-cooperativeness and 10 for ineffectiveness). Each item is rated on a 4-point scale ( 0 = not true at all; 1 = slightly true; 2 = moderately true; and 3 = very true). The T\&P is hierarchically organized and scored across two to eight progressively divergent tiers. At the eight-tier level, molar neuroticism and introversion scores are generated, and the eighth tier has all eight personality facets (anxious worrying, personal reserve, perfectionism, irritability, social avoidance, rejection sensitivity, self-criticism and self-focused).

Intermediate tiers are derived from molar tiers. For instance, the personality style anxious worrying/ sensitivity to other at the fifth tier splits into 'anxious worrying' and 'rejection sensitivity' at the sixth tier, with both lower-order dimensions of the higher-order molar neuroticism construct. The T\&P is available for use free of charge and can be completed in a pen-and-paper format or online in the Black Dog Institute Website (www.blackdoginstitute.org.au). The psychometric properties of the original English version of T\&P were tested in Australian samples and results revealed high internal consistence across its eight subscales (Cronbach's a coefficients ranging from 0.62 to 0.91 ) and high test-retest reliability (intraclass correlation ranging from 0.72 to 0.93 ). The questionnaire had minimal sensitivity to mood state effects and concurrent validity against clinically judged construct scores. ${ }^{6}$

The authors of this study developed a Portuguese version of the T\&P, as described here, and evaluated its psychometric properties, described in another manuscript. ${ }^{14}$

\section{Procedures}

The procedures for translation and adaptation of the T\&P followed guidelines for adapting self-report instruments issued by the Task Force for Translation and Cultural Adaptation of the International Society for Pharmacoeconomics and Outcomes Research (ISPOR). ${ }^{15}$ These guidelines are widely used for translation and adaptation of self-report instruments in various health areas. A detailed discussion of this method was published by our research group in a study for the translation and adaptation of the Measure of Parental Style (MOPS). ${ }^{16}$

Briefly, the translation process had 10 steps $^{15}$ :

1) Preparation: initial work, before the translation process;

2) Forward translation: first translation into the target language;

3) Reconciliation: building a single version merging more than one forward translation;

4) Back translation: translation of the reconciliation version back into the original language;

5) Back translation review: comparison of backtranslated versions with the original to investigate discrepancies;

6) Harmonization: comparison of back translation 
versions with each other and the original instrument to harmonize discrepancies between the reviewed version of the back translation and the original instrument;

7) Cognitive debriefing: application of the instrument to a small number of patients with depression to check understandability, interpretation and cultural relevance of the translation;

8) Review of cognitive debriefing results and finalization;

9) Proof reading; and

10)Final report.

The translation of T\&P started after the author of the original instrument (GP) had been contacted and granted authorization (preparation phase). The first (forward) translations were made by four native speakers of the target language, in two pairs, producing two independent translations. The reconciliation version was produced by a native speaker of the target language not involved in the forward translations.

The back translation was performed by an independent translator, not linked to the project, and who did not know the original instrument or the first translations. The revision of the back translation was performed by the author of the original T\&P (GP).

Five patients with depression were recruited for the cognitive debriefing at de Mood Disorders Program, an outpatient service of Hospital de Clínicas de Porto
Alegre (HCPA) in southern Brazil. The investigation was approved by the medical ethics committee of HCPA, and all participants provided written informed consent.

\section{Results}

Table 1 summarizes the results of the two initial translations, conciliation, back translation and final version. The author's comments suggested adjustments to only eleven items (items 5, 14, 15, 20, 32, 76, $80,88,102,108$ and 109) of the questionnaire, and changes and adjustments were accepted by the Brazilian research group.

After revision of the back translation, the Brazilian version of the T\&P was applied to five outpatients with depression whose native language was Portuguese. For each item, the patients were asked what they understood and whether they had any difficulties or suggestions (cognitive debriefing). This step produced minor adaptations that were incorporated into the final version, along with syntax and spelling revisions. For example, in item 39 (I like lots of social stimulation) the word contato (contact in English) was placed in brackets to reinforce the meaning of the original sentence in English. We did not perform any harmonization, as there are no versions of the T\&P in other languages to compare with our back translation.

Table 1 - Original version, translation, reconciliation, back translation and final version of the Temperament \& Personality Questionnaire (brief format)

\begin{tabular}{|c|c|c|c|c|c|}
\hline Original & Translation 1 & Translation 2 & Reconciliation & $\begin{array}{c}\text { Back } \\
\text { translation }\end{array}$ & Final \\
\hline ( ) Not true at all & $\begin{array}{l}\text { ( ) Não verdadeiro } \\
\text { de qualquer modo }\end{array}$ & ( )Totalmente falso & $\begin{array}{l}\text { ( ) Completamente } \\
\text { não-verdadeiro }\end{array}$ & ( ) False & ( ) Falso \\
\hline ( ) Slightly true & ( ) Pouco verdadeiro & ( ) Um pouco verdadeiro & ( ) Pouco verdadeiro & $\begin{array}{l}\text { ( ) Somewhat } \\
\text { true }\end{array}$ & ( ) Pouco verdadeiro \\
\hline ( ) Moderately true & $\begin{array}{l}\text { ( ) Moderadamente } \\
\text { verdadeiro }\end{array}$ & $\begin{array}{l}\text { ( ) Moderadamente } \\
\text { verdadeiro }\end{array}$ & $\begin{array}{l}\text { ( ) Moderadamente } \\
\text { verdadeiro }\end{array}$ & ( ) Slightly true & $\begin{array}{l}\text { ( ) Moderadamente } \\
\text { verdadeiro }\end{array}$ \\
\hline ( ) Very true & ( ) Muito verdadeiro & $\begin{array}{l}\text { ( ) Completamente } \\
\text { verdadeiro }\end{array}$ & ( ) Muito verdadeiro & ( ) Very true & ( ) Muito verdadeiro \\
\hline $\begin{array}{l}\text { 1. I have more } \\
\text { good qualities than } \\
\text { bad ones. }\end{array}$ & $\begin{array}{l}\text { 1. Eu tenho mais } \\
\text { qualidades do que } \\
\text { defeitos. }\end{array}$ & $\begin{array}{l}\text { Eu tenho mais } \\
\text { qualidades boas do que } \\
\text { ruins. }\end{array}$ & $\begin{array}{l}\text { 1. Eu tenho mais } \\
\text { qualidades do que } \\
\text { defeitos. }\end{array}$ & $\begin{array}{l}\text { 1. I have more } \\
\text { good qualities } \\
\text { than bad ones. }\end{array}$ & $\begin{array}{l}\text { 1. Eu tenho mais } \\
\text { qualidades do que } \\
\text { defeitos. }\end{array}$ \\
\hline $\begin{array}{l}\text { 2. I am usually } \\
\text { the "energiser" at } \\
\text { parties. }\end{array}$ & $\begin{array}{l}\text { 2. Eu geralmente } \\
\text { sou o "energizador" } \\
\text { em festas. }\end{array}$ & $\begin{array}{l}\text { Eu costumo ser o } \\
\text { "animador" nas festas. }\end{array}$ & $\begin{array}{l}\text { 2. Eu costumo ser } \\
\text { o "animador" nas } \\
\text { festas. }\end{array}$ & $\begin{array}{l}\text { 2. I am usually } \\
\text { the "driver of fun } \\
\text { times" at parties. }\end{array}$ & $\begin{array}{l}\text { 2. Eu costumo ser } \\
\text { o(a) "animador(a)" } \\
\text { nas festas. }\end{array}$ \\
\hline $\begin{array}{l}\text { 3. Friends see me } \\
\text { as cooperative and } \\
\text { agreeable. }\end{array}$ & $\begin{array}{l}\text { 3. Amigos me veem } \\
\text { como cooperativo e } \\
\text { agradável. }\end{array}$ & $\begin{array}{l}\text { Os amigos me veem } \\
\text { como cooperativo e } \\
\text { agradável. }\end{array}$ & $\begin{array}{l}\text { 3. Os amigos } \\
\text { me veem como } \\
\text { cooperativo e } \\
\text { agradável. }\end{array}$ & $\begin{array}{l}\text { 3. My friends } \\
\text { see me as } \\
\text { cooperative and } \\
\text { agreeable. }\end{array}$ & $\begin{array}{l}\text { 3. Os amigos } \\
\text { me veem como } \\
\text { cooperativo(a) e } \\
\text { agradável. }\end{array}$ \\
\hline $\begin{array}{l}\text { 4. I always like to } \\
\text { do my best. }\end{array}$ & $\begin{array}{l}\text { 4. Eu sempre gosto } \\
\text { de fazer o meu } \\
\text { melhor. }\end{array}$ & $\begin{array}{l}\text { Eu gosto de fazer } \\
\text { sempre o meu melhor. }\end{array}$ & $\begin{array}{l}\text { 4. Eu gosto de } \\
\text { fazer sempre o meu } \\
\text { melhor. }\end{array}$ & $\begin{array}{l}\text { 4. I always like to } \\
\text { do my best. }\end{array}$ & $\begin{array}{l}\text { 4. Eu gosto de } \\
\text { fazer sempre o meu } \\
\text { melhor. }\end{array}$ \\
\hline $\begin{array}{l}\text { 5. I am generally } \\
\text { described as a nice } \\
\text { person. }\end{array}$ & $\begin{array}{l}\text { 5. Eu geralmente } \\
\text { sou descrito } \\
\text { como uma pessoa } \\
\text { amável. }\end{array}$ & $\begin{array}{l}\text { Eu sou descrito } \\
\text { geralmente como uma } \\
\text { pessoa legal. }\end{array}$ & $\begin{array}{l}\text { 5. Eu sou descrito } \\
\text { geralmente como } \\
\text { uma pessoa legal. }\end{array}$ & $\begin{array}{l}\text { 5. I am generally } \\
\text { described as a } \\
\text { nice (fun) person } \\
\text { to be around. }\end{array}$ & $\begin{array}{l}\text { 5. Eu sou descrito } \\
\text { geralmente como } \\
\text { uma pessoa legal. }\end{array}$ \\
\hline
\end{tabular}




\begin{tabular}{|c|c|c|c|c|c|}
\hline $\begin{array}{l}\text { 6. I am tense and } \\
\text { nervy. }\end{array}$ & $\begin{array}{l}\text { 6. Eu sou tenso e } \\
\text { nervoso. }\end{array}$ & Eu sou tenso e nervoso. & $\begin{array}{l}\text { 6. Eu sou tenso e } \\
\text { nervoso. }\end{array}$ & $\begin{array}{l}\text { 6. I am tense and } \\
\text { nervous. }\end{array}$ & $\begin{array}{l}\text { 6. Eu sou tenso(a) } \\
\text { e nervoso(a). }\end{array}$ \\
\hline $\begin{array}{l}\text { 7. I am very } \\
\text { snappy when I'm } \\
\text { stressed. }\end{array}$ & $\begin{array}{l}\text { 7. Eu sou muito } \\
\text { mordaz quando } \\
\text { estou estressado. }\end{array}$ & $\begin{array}{l}\text { Eu fico muito irritado } \\
\text { quando estou } \\
\text { estressado. }\end{array}$ & $\begin{array}{l}\text { 7. Eu sou muito } \\
\text { ríspido (grosseiro) } \\
\text { quando estou } \\
\text { estressado. }\end{array}$ & $\begin{array}{l}\text { 7. I am quick } \\
\text { to give a sharp } \\
\text { answer when } \\
\text { under stress. }\end{array}$ & $\begin{array}{l}\text { 7. Eu sou muito } \\
\text { ríspido(a) } \\
\text { ("respondão") } \\
\text { quando estou } \\
\text { estressado(a). }\end{array}$ \\
\hline $\begin{array}{l}\text { 8. I am very } \\
\text { uneasy about } \\
\text { opening up to } \\
\text { other people. }\end{array}$ & $\begin{array}{l}\text { 8. Eu sou muito } \\
\text { receoso sobre me } \\
\text { abrir para outras } \\
\text { pessoas. }\end{array}$ & $\begin{array}{l}\text { Eu fico apreensivo em } \\
\text { me abrir com as outras } \\
\text { pessoas. }\end{array}$ & $\begin{array}{l}\text { 8. Eu sou } \\
\text { muito receoso } \\
\text { (constrangido) } \\
\text { sobre me abrir para } \\
\text { outras pessoas. }\end{array}$ & $\begin{array}{l}\text { 8. I don't feel } \\
\text { comfortable (am } \\
\text { uneasy) about } \\
\text { opening up with } \\
\text { other people. }\end{array}$ & $\begin{array}{l}\text { 8. Eu não me } \\
\text { sinto à vontade } \\
\text { (constrangido/a) } \\
\text { para me abrir com } \\
\text { outras pessoas. }\end{array}$ \\
\hline * & * & * & * & * & * \\
\hline $\begin{array}{l}\text { Thank you for } \\
\text { completing this } \\
\text { questionnaire. }\end{array}$ & $\begin{array}{l}\text { Obrigado por } \\
\text { completar esse } \\
\text { questionário. }\end{array}$ & $\begin{array}{l}\text { Obrigado por responder } \\
\text { este questionário. }\end{array}$ & $\begin{array}{l}\text { Obrigado por } \\
\text { completar esse } \\
\text { questionário. }\end{array}$ & $\begin{array}{l}\text { Thank you for } \\
\text { completing this } \\
\text { questionnaire. }\end{array}$ & $\begin{array}{l}\text { Obrigado por } \\
\text { completar este } \\
\text { questionário. }\end{array}$ \\
\hline
\end{tabular}

* The complete table with the 109 items is available from the authors upon request.

\section{Discussion}

This study briefly described the translation and crosscultural adaptation of T\&P into Brazilian Portuguese using the method prescribed by the TCA task force. ${ }^{15}$ To our knowledge, this is the first translation of T\&P. The translation followed a standardized process and required minor adaptations.

This version of the T\&P has already been used in Brazil in studies already published. ${ }^{13}$ In clinical settings, the T\&P has advantages over other personality measures, as it assesses personality styles specifically overrepresented in patients with clinical depression and follows a bottomup approach. ${ }^{7}$ Because of this structure, at the fourth tier each of its four personality styles is consistent with the big four factors of the dominant FFM of personality: anxious worrying/sensitivity to others in T\&P is equivalent to neuroticism in FFM; irritability, to disagreeableness; perfectionism, to conscientiousness; and personal/social reserve, to introversion. ${ }^{6}$ Therefore, construct validity has been suggested for its original English version.

Another potential advantage is its flexible format of eight tiers, which allows for broad investigations that range from molar factors at its second tier to more fine-grained analyses examining up to eight factors at its eighth tier. It may be used in studies to investigate the association between personality and depression (e.g., risk of onset and response to treatment) as well as to examine specificity to non-melancholic depressive subtypes, such as atypical depression. ${ }^{17}$

In summary, the Brazilian version of the T\&P was translated and adapted following rigid standardized international guidelines and is already available for use, although its validation is ongoing. Future adaptations to other languages should use the same process and be compared with our back translation. We believe that this versatile instrument may be especially useful to investigate the association between personality styles and depressive conditions.

\section{Acknowledgement}

Lucas Spanemberg receives a PhD scholarship from Coordenação de Aperfeiçoamento de Pessoal de Nível Superior (CAPES). Gordon Parker is funded by a grant from the National Health and Medical Research Council (NHMRC) (program no. 1037196). This work was partially supported by Fundo de Incentivo à Pesquisa e Eventos - Hospital de Clínicas de Porto Alegre (FIPE/HCPA; project no. 09-176).

\section{References}

1. Widiger TA. Personality and psychopathology. World Psychiatry. 2011;10:103-06.

2. Bagby RM, Psych C, Quilty LC, Ryder AC. Personality and depression. Can J Psychiatry. 2008;53:14-25.

3. Livesley WJ, Jang KL, Vernon PA. Phenotypic and genetic structure of traits delineating personality disorder. Arch Gen Psychiatry. 1998;55:941-8.

4. McCrae RR, Costa PT. More reasons to adopt the Five-Factor Model. Am Psychol. 1989;44:451-2.

5. Samuel DB, Simms LJ, Clark LA, Livesley WJ, Widiger TA. An item response theory integration of normal and abnormal personality scales. Personal Disord. 2010;1:5-21.

6. Parker G, Manicavasagar V, Crawford J, Tully L, Gladstone G. Assessing personality traits associated with depression: the utility of a tiered model. Psychol Med. 2006;36:1131-9. Epub 2006 May 2.

7. Parker GB, Crawford J. A spectrum model for depressive conditions: extrapolation of the atypical depression prototype. J Affect Disord. 2007;103:155-63. Epub 2007 Feb 16.

8. Parker G, Malhi G, Mitchell P, Wilhelm K, Austin MP, Crawford J, et al. Progressing a spectrum model for defining non-melancholic depression. Acta Psychiatr Scand. 2005;111:139-43.

9. Parker G, Roy K. Examining the utility of a temperament model for modelling non-melancholic depression. Acta Psychiatr Scand. 2002;106:54-61.

10. Parker G, Hadzi-Pavlovic D, Roussos J, Wilhelm K, Mitchell P, Austin MP, et al. Non-melancholic depression: the contribution of personality, anxiety and life events to subclassification. Psychol Med. 1998;28:1209-19.

11. Boyce P, Parker G, Barnett B, Cooney M, Smith F. Personality as a vulnerability factor to depression. Br J Psychiatry. 1991;159:106-14. 
12. Black Dog Institute [Internet]. Temperament \& Personality (T\&P) Questionnaire. http://www.blackdoginstitute.org.au/public/ research/researchtools.cfm. Accessed 2013 nov 15.

13. Caldieraro MA, Baeza FL, Pinheiro DO, Ribeiro MR, Parker G, Fleck MP. Clinical differences between melancholic and nonmelancholic depression as defined by the CORE system. Compr Psychiatry. 2013;54:11-5. Epub 2012 Jul 6.

14. Spanemberg L, Salum GA, Caldieraro MA, Vares EA, Tiecher RD, Rocha NS, et al. Personality styles in depression: testing reliability and validity of hierarchically organized constructs. Pers Individ Dif. 2014;70:72-9

15. Wild D, Grove A, Martin M, Eremenco S, McElroy S, VerjeeLorenz $A$, et al. Principles of Good Practice for the Translation and Cultural Adaptation Process for Patient-Reported Outcomes (PRO) Measures: report of the ISPOR Task Force for Translation and Cultural Adaptation. Value Health. 2005;8:94-104.

16. Baeza FLC, Caldieraro MAK, Pinheiro DO, Fleck MP. Translation and cross-cultural adaptation into Brazilian Portuguese of the
Measure of Parental Style (MOPS) - a self-reported scale according to the International Society for Pharmacoeconomics and Outcomes Research (ISPOR) recommendations. Rev Bras Psiquiatr. 2010;32:159-63.

17. Parker G, Roy K, Mitchell P, Wilhelm K, Malhi G, Hadzi-Pavlovic D. Atypical depression: a reappraisal. Am J Psychiatry. 2002;159:1470-9.

\section{Correspondence:}

Lucas Spanemberg

Hospital São Lucas da PUCRS

Psychiatric Unit, $6^{\circ}$ Andar Sul

Av. Ipiranga, 6690, Jardim Botânico

90610-000 - Porto Alegre, RS - Brazil

Tel.: +55 (51) 3320.3041

E-mail: Ispanemberg@yahoo.com.br 